Conclusion: Preliminary data seem to indicate that abatacept can promote the in vitro shift from the M1 into the M2 macrophage phenotype, by upregulating specific markers (CD163, CD204, CD206) in cultured M1-MDMs from RA patients and in M1 macrophages induced from HS.

REFERENCES:

[1] Mclnnes IB, et al. N Engl J Med 2011;365:2205-19.

[2] Fujii M, et al. Biochem Biophys Res Commun. 2013;438(1):103-9.

[3] Cutolo M, et al. Arthritis Res Ther. 2009;11:R176.

[4] Pelegrin P., Surprenant, A. EMBO J. 2009 Jul 22; 28(14): 2114-2127.

Disclosure of Interests: Samuele Tardito: None declared, Stefano Soldano: None declared, Emanuele Gotelli: None declared, Paola Montagna: None declared, Sabrina Paolino: None declared, Vanessa Smith: None declared, Maurizio Cutolo Grant/research support from: I received grant/research support from Bristol-Myers Squibb, Boehringer, Celgene.

DOI: 10.1136/annrheumdis-2021-eular.2524

\section{AB0058 ASSOCIATION BETWEEN HLA-DRB1*04:01, RHEUMATOID NODULES AND PARTICULAR EPITOPES OF CITRULLINATED FIBRIN IN PATIENTS WITH RHEUMATOID ARTHRITIS}

G. Larid ${ }^{1}$, M. Pancarte ${ }^{2}$, G. Offer ${ }^{2}$, C. Clavel ${ }^{2,3}$, M. Martin ${ }^{4}$, V. Pradel ${ }^{5}$, I. Auger $^{4}$, P. Lafforgue ${ }^{1}$, G. Serre ${ }^{2}$, J. Roudier ${ }^{1,4}$, N. Balandraud ${ }^{1,4} .{ }^{1} A P-H M$, Rheumatology, Marseille, France, ${ }^{2}$ UDEAR, Toulouse 2 University, INSERM U1056, Toulouse, France: ${ }^{3}$ Centre Hospitalier Universitaire (CHU) de Toulouse, Institut Fédératit de Biologie, Laboratory of Cell Biology and Cytology, Toulouse, France; ${ }^{4}$ AixMarseille-University, INSERM UMRs 1097 Arthrites Auto Immunes, Marseille, France; ${ }^{5} \mathrm{AP}-\mathrm{HM}$, Public Health Laboratory, Marseille, France

Background: Rheumatoid arthritis (RA) is associated with HLA-DRB1 genes encoding the shared epitope (SE), a 5 amino acid motive. RA is usually preceded by the emergence of anti-citrullinated protein antibodies (ACPAs) detected by anti-CCP2 tests. Citrullin is a neutral amino acid resulting from post translational modification of arginin by Peptidyl Arginyl Deiminases (PADs). ACPAs recognize epitopes from citrullinated human fibrinogen (Fib-cit) and can be specifically detected by the AhFibA assay. Five peptides derived from Fib-cit together represent almost all of the epitopes recognized by patients with ACPA-positive RA: $\beta 60-74$ cit, $\alpha 36-50$ cit, $\alpha 621-635$ cit, $\alpha 501-515$ cit and $\alpha 171-185$ cit. As RA is a pleiomorphic disease, whose evolution is difficult to predict, the use of antibody fine specificity as a marker of clinical phenotypes has become a major challenge. Objectives: Our objective was to study whether clinical characteristics and HLADRB1 genetic background were associated with a specific reactivity against these epitopes.

Methods: 184 ACPA positive RA patients fulfilling the 2010 ACR/EULAR criteria were studied. Patients characteristics, including HLA-DRB1 genotype, were collected from their medical files. Anti-CCP2, AhFibA, Rheumatoid Factors (RF), and antibodies against the five major Fib-cit peptides were analyzed using ELISA assays.

Results: Anti-CCP2 and AhFibA titres were strongly correlated (rs: $0.7037 ; \mathrm{p}=$ $5.69 \times 10^{-29}$, Pearson's). Anti- $0505-515$ cit antibodies were associated with HLADRB1 ${ }^{*} 04: 01(\mathrm{OR}=5.52$ [2.00 - 13.64]; $p=0.0003)$. High level anti- $\alpha 505-515 \mathrm{cit}$ antibodies were significantly associated with rheumatoid nodules $(\mathrm{OR}=2.71$ $[1.00-7.16], p=0.044)$. Anti $\alpha 501-515$ cit antibodies were associated with RF $(\mathrm{OR}=2.31[1.10-4.78], \mathrm{p}=0.026)$.

Conclusion: Immune complexes containing anti- $\alpha 501-515$ cit antibodies and rheumatoid factors might be involved in the development of rheumatoid nodules on the HLA-DRB1*04:01 background. These findings highlight the role played by the HLA-DRB1*04:01 molecule and its rapid intracellular route into the lysosomes, enabling original antigen processing. Finally, purifying these epitope specific antibodies might be a new therapeutic opportunity for rheumatoid nodules. Disclosure of Interests: None declared

DOI: 10.1136/annrheumdis-2021-eular.2568

\section{AB0059 STUDY OF THE ANTI-INFLAMMATORY EFFECT OF CINNAMOMUM VERUM IN RATS}

R. Dhouibi ${ }^{1}$, A. Hanène ${ }^{1}$, S. Ben Youssef ${ }^{2}$, M. Ben Salem ${ }^{3}$, R. Marrakchi ${ }^{4}$ S. Charfi ${ }^{5}$, S. Hammami ${ }^{1}$, K. Ksouda ${ }^{1}{ }^{1}$ Medecine School of Sfax,

Pharmacology Department, Sfax, Tunisia; ${ }^{2}$ University of Sfax, Higher Institute of Biotechnology of Sfa, Sfax, Tunisia; ${ }^{3}$ University of Sfax, Laboratory of Biochimie, Hedi Chaker Hospital Sfax, Sfax, Tunisia; ${ }^{4}$ Hedi Chaker Hopital, Laboratory of Biochimie, Sfax, Tunisia; ${ }^{5}$ Habib Bourguiba Hopital, Laboratory of Histology, Sfax, Tunisia

Background: Inflammatory response is a common physiological response that protects the host of many harmful stimuli such as toxins, local injuries and pathogens. Today, non-steroidal anti-inflammatory drugs are the most commonly prescribed for the treatment of many inflammatory treatments. However, long term administration of these NSAIDs causes many adverse effects, including gastrointestinal ulcers and bleeding and kidney damage. Therefore, the need for new anti-inflammatory drugs with fewer side effects is required.

Objectives: The aim of our study was to evaluate the anti-inflammatory activity of Cinnamomum verum (C. Verum) on rats while testing the dose effect and the typical effect of the solvent.

Methods: The edema was induced by injection of carrageenan solution (CARR) in paw of rats according to the method of Winter et al, 1963. The measurements of volumes of right hind paw of each rat were taken before induction of edema and each $1 \mathrm{~h}, 2 \mathrm{~h}, 3 \mathrm{~h}, 4 \mathrm{~h}$ and $5 \mathrm{~h}$ after the injection of carrageenan. 7 groups of 6 rats received, one hour before the injection of the carrageenan, different treatment: G1 = witness, G2=CARR + saline solution, G3= CARR + Acetylsalicylic acid, G4 = CARR + C. verum- MeOH 100, G5 = CARR + C. verum $-\mathrm{MeOH} 300$ $\mathrm{G} 6=\mathrm{CARR}+\mathrm{CARR}+$ C. verum $-\mathrm{EtOH} 100$ and G7 $=\mathrm{CARR}+$ C.verum $-\mathrm{EtOH}$ 300.

Results: For this test, the volume of edema increases with time, this increase is greater in the group treated with saline solution than with the extracts of $C$.Verum and with Acetylsalicylic acid. The extracts of $C$. Verum administered intraperitoneally one hour before the injection of the carrageenan, reduced the edema in the third hour after.

Conclusion: The interesting anti-inflammatory activity of Cinnamomum verum recorded in this work may at least in part support its popular use in traditional medicine $[1,2]$.

\section{REFERENCES:}

[1] Mirza Muhammad Fahd Qadir, Attya Bhatti, Muhammad Usman Ashraf, Mansur Abdullah Sandhu, Sidrah Anjum, Peter John. Immunomodulatory and therapeutic role of Cinnamomum verum extracts in collagen-induced arthritic BALB/c mice. Inflammopharmacology 2018 Feb;26(1):157-170.

[2] Heping Cao, Joseph F Urban Jr, Richard A Anderson. Cinnamon polyphenol extract affects immune responses by regulating anti- and proinflammatory and glucose transporter gene expression in mouse macrophages. J Nutr 2008 May; 138(5):833-40

Disclosure of Interests: None declared

DOI: 10.1136/annrheumdis-2021-eular.2948

\section{AB0060 INCREASED AGE/AUTOIMMUNE-ASSOCIATED B CELLS IN RA AND CLINICAL IMPLICATIONS}

\section{Y. QIN ${ }^{1}$, Z. CHEN ${ }^{1} .{ }^{1}$ THE FIRST AFFILIATED HOSPITAL OF USTC, RHEUMATOLOGY AND IMMUNOLOGY, HEFEI, CHINA}

Background: Age/Autoimmune-associated $B$ cells ( $A B C s$ ) are an emerging $B$ cell subset that accumulate in aged and autoimmune-prone mice. Expansion of human $A B C$ s has been observed in patients with autoimmune diseases like SLE and correlated with disease activity. However, it is less known whether ABCs contribute to the pathogenesis of RA.

Objectives: The aim of this work was to explore the role of $A B C s$ in RA.

Methods: 83 RA patients who met the 2010 ACR classification criteria for RA, 42 sex and age matched healthy control $(\mathrm{HC}), 35$ Spondyloarthritis $(\mathrm{SpA})$ and 31 Osteoarthritis $(\mathrm{OA})$ patients were enrolled and blood samples were collected. The proportion of circulating ABCs was detected by flow cytometry and association with clinical and laboratory parameters were analyzed. Expression of characteristic proteins and inflammatory cytokines on ABCs were examined by quantitative real-time PCR.

Results: The proportion of $A B C s$, defined as $C^{2} 19^{+} C D 27^{-}$IgD ${ }^{-} C D 21{ }^{-} C D 11 c^{+}$ was significantly elevated in RA patients, compared with $\mathrm{HC}, \mathrm{SpA}$ and $\mathrm{OA}$ patients. The frequency of $A B C s$ was higher in patients with high disease activity (DAS28>3.2) compared with remission and low disease activity (DAS28<3.2). There was a positive correlation of ABCs with SJC, TJC, DAS28 whereas no association with RF and anti-CCP titer were observed. In addition, increased mRNA expression levels of T-bet, IL-21, MAF and IL-17 were noted on ABCs compared with $\mathrm{CD} 19^{+} \mathrm{CD} 27^{-} \mathrm{CD} 11 \mathrm{c}^{-} \mathrm{B}$ cells.

Conclusion: $A B C$ s were expanded in RA patients and associated with active disease status. It might contribute to RA development by production of IL-17.

\section{REFERENCES:}

[1] Cancro, M.P., Age-Associated B Cells. Annu Rev Immunol, 2020. 38(315-340).

[2] F. Zhang, K. Wei, K. Slowikowski et al., Defining inflammatory cell states in rheumatoid arthritis joint synovial tissues by integrating single-cell transcriptomics and mass cytometry. Nat Immunol 2019, 20, 928-942.

Disclosure of Interests: None declared

DOI: 10.1136/annrheumdis-2021-eular.3026 